\title{
Tooth Infection
}

National Cancer Institute

\section{Source}

National Cancer Institute. Tooth Infection. NCI Thesaurus. Code C78639.

An infectious process affecting a tooth. 